\title{
Новая стратегия селекции и семеноводства картофеля - перспективы и направления развития
}

\author{
Т.А. Гавриленко* \\ ФИЦ Всероссийский институт генетических ресурсов растений имени Н.И. Вавилова (ВИР), \\ Санкт-Петербург, Россия \\ *e-mail:tatjana9972@yandex.ru
}

Методы создания высокопродуктивных гетерозисных гибридов, получаемых от межлинейных скрещиваний, широко используются для кукурузы, подсолнечника, сорго, риса, перца и других культурных растений. Для повышения эффективности массового производства гибридных семян этих культур в скрещивания вовлекают инбредные родительские линии с разными типами мужской стерильности - генной (ГМС), цитоплазматической (ЦМС), а также линии, несущие доминантные аллели генов восстановления фертильности пыльцы $(R f)$.

Для возделываемого картофеля Solanum tuberosum $(2 n=4 x=48)$ - важнейшей незерновой продовольственной культуры, размножаемой вегетативно, данное направление селекции и семеноводства ранее не разрабатывалось. Традиционные методы селекции картофеля существенно затрудняет ряд генетических факторов: стерильность многих форм, автотетраплоидность, высокий уровень гетерозиготности, тетрасомное наследование признаков и проявление сильной инбредной депрессии. Вегетативный способ размножения картофеля, способствующий накоплению вирусных и других инфекций, осложняет репродукционное размножение селекционных сортов; эта проблема в настоящее время решается с использованием достаточно затратных и длительных технологий безвирусного семеноводства.

Недавно ряд голландских и североамериканских генетиков и селекционеров (Lindhout et al., 2011; Jansky et al., 2016) предложили новую стратегию развития селекции и семеноводства картофеля, основанную на создании диплоидных инбредных линий, линейно-гибридной селекции и использовании технологий TPS (True Potato Seeds). Прогнозируемыми преимуществами новой стратегии является: кардинальное сокращение сроков селекционного процесса за счет повышения эффективности отбора на диплоидном уровне генотипов с аллелями генов, детерминирующих ценные признаки, и элиминации генотипов с аллелями генов, ассоциированных с инбредной депрессией и негативными свойствами; a также возможность сокращения длительных и затратных технологий безвирусного семеноводства, поскольку подавляющее большинство патогенов с пыльцой не передается. Lindhout et al. $(2017,2018)$ продемонстрировали первые успешные результаты оценки диплоидных гетерозисных гибридов картофеля, продуктивность которых не уступала коммерческим тетраплоидным сортам; эти гибриды получают на основе кастрации и опыления вручную инбредных диплоидных линий. Обсуждаются перспективы исследований генетических систем ЦМС-Rf у картофеля, актуальность которых была обоснована Анисимовой и Гавриленко (2017), в целях повышения эффективности селекции диплоидных гетерозисных гибридов.

Благодарности: Работа выполнена при финансовой поддержке гранта РНФ № 16-16-04125. 